\title{
本態性血小板血症を合併した大動脈弁置換術の 1 症例
}

$\begin{array}{llllll}\text { 松 村 洋 高 } & \text { 佐々木 達海 } & \text { 蜂 谷 貴 } \\ \text { 小野口 } & \text { 勝久 } & \text { 高 倉 宏 } & \text { 充 } & \text { 橋 本 和 弘* }\end{array}$

\begin{abstract}
本態性血小板血症は慢性骨髄増殖性疾患に属する希な疾患であり，末梢血の持続的な血小板増多と光の機能 障害に起因する血栓形成傾向と易出血性傾向を併せもつ疾患である. 今回，われわれは本態性血小板血症を 合併した大動脈弁狭窄症に対し，生体弁による大動脈弁位人工弁置換術を施行した。術前の血小板数は 80 万/ $\mu \mathrm{l}$ であったが，特別な処置を施行せずに手術を行った，術中はへパリンにて ACTを 400 秒以上に維持 した。術後，抗血小板療法としてバイアスピリンを投与した。 また，人工弁に対する抗凝固療法としてワー ファリンを投与し， TT を $30 \%$ 前後に管理していたが血小板数が 130 万/ $\mu \mathrm{l}$ まで上昇したためヒドロキシウ レア (ハイドレア) による化学療法を開始し血小板数を 100 万/ $\mu 1$ 前後にコントロールした. 術中, 術後と もに出血, 血栓の合併症もなく良好な経過を示した. 日心外会誌 33 巻 2 号 : 129-132（2004）
\end{abstract}

Keywords : 本態性血小板血症, 大動脈弁置換術, ヒドロキシウレア

\begin{abstract}
Aortic Valve Replacement Associated with Essential Thrombocythemia
Yohkoh Matsumura, Tatsuumi Sasaki, Takashi Hachiya, Katsuhisa Onoguchi, Hiromitsu Takakura and Kazuhiro Hashimoto* (Department of Cardiovascular Surgery, Saitama Cardiovascular and Respiratory Center, Saitama, Japan and Department of Cardiac Surgery, Jikei University School of Medicine*, Tokyo, Japan)

Essential thrombocythemia is a rare disease belonging to the group of chronic myeloproliferative disorders. It displays both thrombogenic and bleeding tendencies due to increased platelet counts, as well as dysfunction. Aortic valve replacement with a $23 \mathrm{~mm}$ Carpentier-Edwards bioprosthesis was performed for a 74-year-old man with aortic stenosis associated with essential thrombocythemia. No pre-treatment was performed before surgery, though the platelet count was $80 \times 10^{4} / \mu 1$. During the surgery, activated coagulation time was kept over $400 \mathrm{sec}$ with heparin. There was no difficulty with hemostasis. Aspirin and warfarin were used as antiplatelet and anticoagulant agents after surgery, so the thrombin test results were controlled at around $30 \%$. Since the platelet count reached $130 \times 10^{4} / \mu 1$, hydroxyurea as chemotherapy was given to suppress the platelet count below $100 \times 10^{4} / \mu 1$. The operation was completed without major problems and the postoperative course was uneventful. This patient remains in good condition. Jpn. J. Cardiovasc. Surg. 33 : 129-132 (2004)
\end{abstract}

本態性血小板血症は慢性骨髄増殖性疾患の一つである. 末梢血の持続的な血小板増多と機能障害に起因する血栓形 成傾向と易出血性傾向の相反する二面を併せもつ複雑な病 態を有し，その続発症が予後を左右するといわれている. 本症を合併する症例に対する人工弁置換術の報告はきわめ て希であり, その病態から術中の出血傾向と術後の血栓症 が懸念される.今回，本態性血小板血症を合併した大動脈 弁狭窄症に対し, 生体弁による大動脈弁位人工弁置換術を 経験したので若干の考察を加えて報告する。

\section{症例}

症例：74 歳, 男性.

2003 年 3 月 12 日受付, 2003 年 9 月 1 日採用

埼玉県立循環器・呼吸器病センター心臓血管外科

干 360-0105 埼玉県大里郡江南町板井 1696

* 東京慈恵会医科大学心臓外科
主訴：労作時呼吸苦, 動悸.

既往歴：脳梗塞.

現病歴：労作時呼吸苦および動悸を主訴に近医を受診し た. 心雑音を認め, 大動脈弁狭窄症の疑いにて当センター 紹介となった。

胸部 Xp：CTR 65\%と心拡大を認めた。

12 誘導心電図：洞調律であったが著明な左室肥大と ST 変化を認めた.

心臓超音波検査（UCG）（図 1）：大動脈弁の高度石灰化 を認め, 弁口面積は $0.5 \mathrm{~cm}^{2}$ であった. 左室一上行大動脈 間の圧較差は $120 \mathrm{mmHg}$ で, 大動脈弁狭窄症と診断した. なお，左室駆出率は $30 \%$ な゙り，心機能の低下を認めた。

血液検査（表 1 ）：血小板数は 80 万 $/ \mu 1$ と高值であり, さらにAPTTは 80.5 秒と延長していた. 反応性血小板 増多症は否定的であったため，血液疾患を疑い骨髄穿刺を 施行した。 
ヘマトキシリンエオジン染色（図 2 左）：巨核球の増生 を認めた。

メイグリュンワルトギムザ染色（図 2 右）：骨髄球系の 成熟と赤芽球系の成熟は保たれており，骨髄の線維化は認 められなかった。末梢血が混入しており，血小板の凝集像 と増多を認めた。また，染色体異常も認めず，本態性血小 板血症と診断した. 血小板数は 80 万/ $\mu 1$ と高值であった が，血小板増多に対する術前処置はとくに施行しなかー た.

術中はへパリンにて活性化凝固時間（ACT）を 400 秒 以上に維持し, 生体弁による大動脈弁位人工弁置換術を施

表 1 術前血液検査データ

\begin{tabular}{lrlr}
\hline WBC & $13.1 \times 10^{3} / \mu \mathrm{l}$ & APTT & $80.5 \mathrm{sec}$ \\
$\mathrm{RBC}$ & $350 \times 10^{4} / \mu \mathrm{l}$ & PT & $13.2 \mathrm{sec}$ \\
$\mathrm{Hb}$ & $9.5 \mathrm{~g} / \mathrm{dl}$ & Fib & $430 \mathrm{mg} / \mathrm{dl}$ \\
$\mathrm{Ht}$ & $29.7 \%$ & FDP & $5.6 \mu \mathrm{g} / \mathrm{ml}$ \\
$\mathrm{Plt}$ & $80.0 \times 10^{4} / \mu \mathrm{l}$ & AT- II & $95 \%$ \\
B.T & $1.5 \mathrm{~min}$ & D-D & $3.86 \mu \mathrm{g} / \mathrm{ml}$ \\
\hline
\end{tabular}
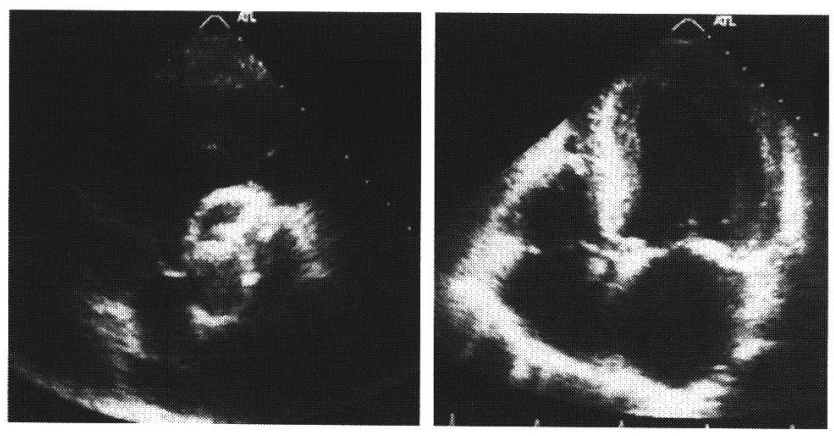

図 1 心臓超音波検査

左：大動脈弁短軸像, 右：四腔像。大動脈弁口面積 $0.5 \mathrm{~cm}^{2}$, 左室-上行大動脈圧較差 $120 \mathrm{mmHg}$, 左室駆出率 $30 \%$.
行した。術中, 易出血性傾向は認められなかった。術後, 本態性血小板血症に対する抗血小板療法としてバイアスピ リンを投与した。 また，人工弁に対する抗凝固療法として ワーファリンを投与し，トロンボテスト（TT）を $30 \%$ 前 後に管理していたが血小板数が 130 万/ $\mu 1$ まで上昇したた めハイドレア $(1,500 \mathrm{mg} / \mathrm{day})$ にる化学療法を開始し 血小板数を 100 万 $/ \mu 1$ 前後にコントロールした。術後の UCGでは心内血栓を認めなかった。

考 察

本態性血小板血症は慢性骨髄増殖性疾患に分類される比 較的希な疾患であり，末悄血の持続的な血小板増多と機能 障害に起因する血栓形成傾向と易出血性傾向の相反する二 面を併せもつ複雑な疾患である。報告により頻度はまちま ちであるが血栓症が 9 22\%程度, また, 出血傾向が 3〜 $37 \%$ 程度に発症するとされている。本症は慢性骨髄性白血 病と異なり，急性転化や致命的合併症はきわめて希であ り，自然予後は一般的に良好であるとされているが，その 続発症（脳梗塞, 心筋梗塞, 肺梗塞など）が予後を左右す るともいわれている1 3). 本態性血小板血症の診断 ${ }^{4}($ 表 2) は基本的に除外診断である。血小板増多症を認めた場合の 鑑別診断としてまず反応性血小板増多症が考えられ，その 基礎疾患として鉄欠乏性賀血, 脾欠損, 転移性癌, 急性出 血, 溶血, 感染症, 炎症性疾患などがあげられる。さらに ほかの骨髄増殖性疾患（慢性骨髄性白血病, 真性赤血球増 多症，骨䯣線維症）を除外する必要がある。また，骨骨道異 形成症候群をも鑑別する必要がある. 本症例は血小板数 80 万/ $\mu 1$, Ht 29.7\%であり, 染色体異常を認めず，骨髄 像で巨核球の増生を認めた。また，骨骨迶の線維化は認めら れなかった。ささらに, 反応性血小板増多症をきたす基礎疾
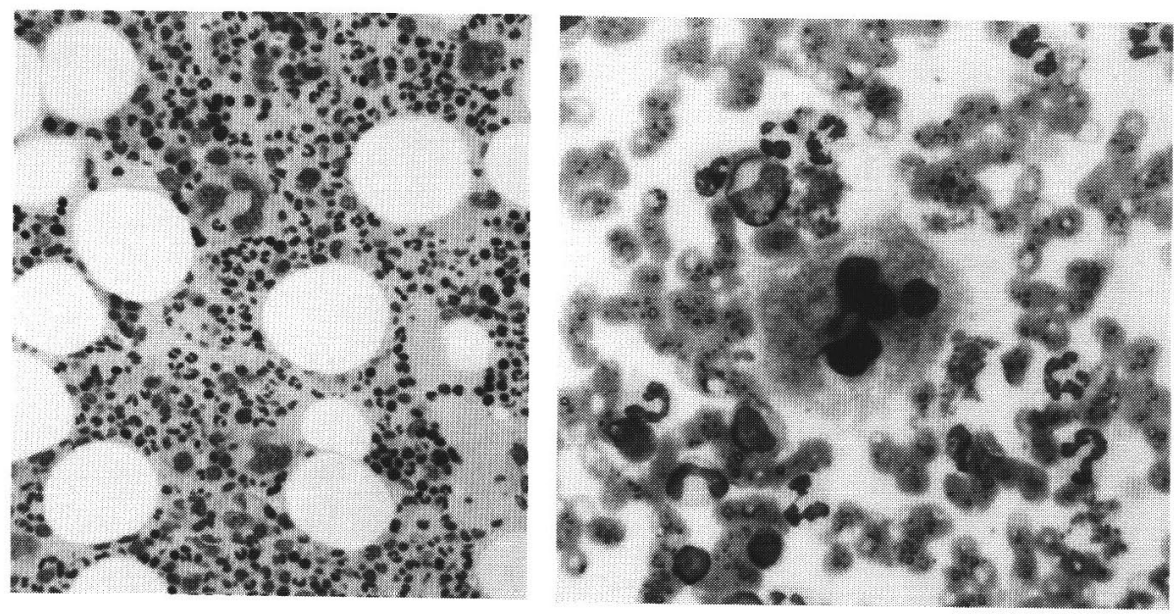

図 2 骨髄 像

左：ヘマトキシリンエオジン染色（倍率 $\times 40 ）$ ，右：メイグリュンワルトギムザ染色（倍 率 $\times 40)$. 
表 2 本態性血小板血症の診断基準
1）血小板数 $60 \times 10^{4} / \mu 1$ 以上.
2）へマトクリットが $40 \%$ 以下あるいは循環赤血球量が正常（男子 $36 \mathrm{ml} / \mathrm{kg}$ 末満, 女子 $32 \mathrm{ml} / \mathrm{kg}$ 未満).
3）骨髄に可染性鉄を認めるか，血清フェリチン值正常，あるいは MCV 正常*.
4） $\mathrm{Ph}^{1}$ 染色体陰性であるか，あるいは bcr/abl 遺伝子の再構成を認めない.
5）骨髄の膠原線維による線維化.
A. 認められない，または
B. 線維化は組織標本の $1 / 3$ 以下で著明な脾腫や白赤芽球症をともに認めない.
6）骨髄異形成症候群にみられる染色体異常や形態学的特徵を認めない.
7） 反応性の血小板増加症をきたす基礎疾患がない.
*これらの検査值で鉄欠乏が疑われる場合は，鉄剤を投与しても循環赤血球量が真性多血症の
基準（男子 $36 \mathrm{ml} / \mathrm{kg}$ 以上，女子 $32 \mathrm{ml} / \mathrm{kg}$ 以上）を満たさないことが条件.

患は否定的であったため, 本態性血小板血症と診断した (表 2).

本態性血小板血症合併例に対して開心術を施行する場 合，問題となることは出血である．しかしながら，出血の 予防に関しては現実問題として積極的な予防法は存在せ ず，慎重かつ丁寧な手術が原則である。一方，術後には血 栓形成が問題となる。人工弁置換術後の血栓塞栓症, 冠動 脈バイパス術後であればグラフトの閉塞である。本態性血 小板血症に対する治療には血小板減少療法, 抗血小板療 法，血栓症の危険因子の除去などがあり，血小板数を正常 化させることが主体である ${ }^{3,5}$. 開心術を施行する場合に も術後血栓形成の予防目的で術前に何らかの方法で血小板 数をコントロールすることも多( $\left.{ }^{6 \sim 10}\right)$ が，術前に血小板数 のコントロールを施行せずに開心術を施行した症例も報告 されている ${ }^{11,12)}$. 血小板数のコントロールの方法は瀉血 ${ }^{6)}$ や血小板フェレーシスを施行する方法7や，抗腫瘍郕を投 与する方法 ${ }^{8 \sim 10)}$ などがある. しかし，血小板数と血栓症の 発症リスクとの間には明らかな関連を見出すことは困難 で，血小板数が極端に増加している症例（150万/ $\mu 1$ 以上） を除いて，血小板数のみでは必ずしも治療開始の目安にな らない.また，逆に血小板数が 200 万/ $\mu 1$ 以上となると出 血のリスクが高くなり血小板数を下げる治療が必要だとも いわれている ${ }^{3)}$. 本症例の術前の血小板数は 80 万/ $\mu 1$ で あったため，血小板数のコントロールを施行しなかった。 術中は通常のへパリン量 (300 単位 $/ \mathrm{kg})$ にて ACTを 400 秒以上に維持し，プロタミン中和後の止血においても何ら 問題なく，無事に人工弁置換術を終了しており，術前の血 小板数のコントロールは必ずしも必須でない可能性が示唆 された.

本態性血小板血症は，年齢 60 歳以上または血栓症の既 往歴がある症例を high risk group とし, 化学療法, 抗血 小板療法が必要であるといわれている。また，年齢 60 歳 以下，血栓症の既往歴がなく，血小板数 150 万/ $\mu 1$ 以下， 心, 脳血管障害の危険因子 (喫煙, 肥満, 高脂血症, 高血

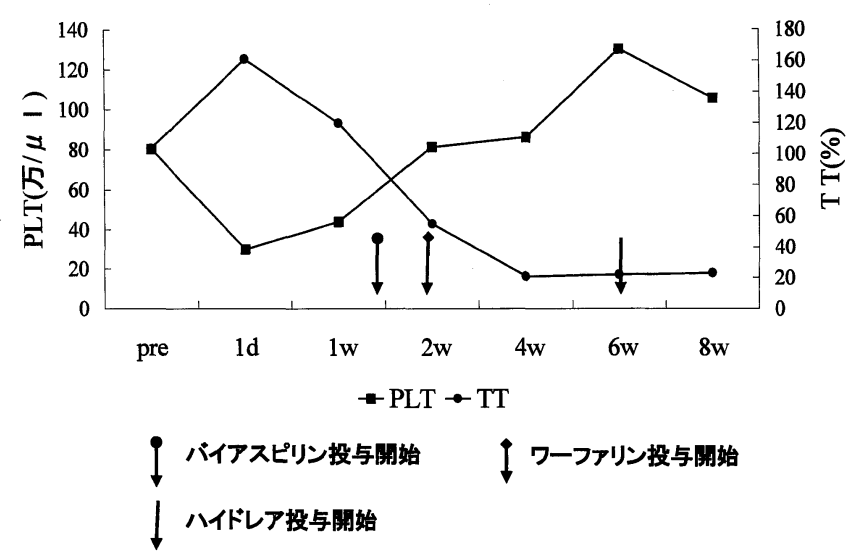

図 3 術後経過

圧，糖尿病など）がない症例を low risk group とし，経 過観察でもよいとされている3,5). 今回の症例は 74 歳と高 齢で, 脳梗塞の既往もあり high risk group に相当し, そ のため, 術直後はへパリンにて ACT 140 秒前後に維持 し, 患者自身の体力的な問題から内服開始が遅くなった が, 術後 10 病日目から抗血小板療法としてバイアスピリ ンの投与を開始し（血小板数 50 万 $/ \mu 1)$ ，その翌日からへ パリンの投与を中止した，易出血性傾向がないことを確認 したうえで，術後 14 病日目よりワーファリンの投与を開 始し（血小板数 80 万 $/ \mu 1$ ), TTを $30 \%$ 前後に管理した. Cortelazzo らによると, high risk group 用群と非使用群に別け経過観察したところ, 使用群では $3.4 \%$ に, 非使用群では $24 \%$ に出血または血栓症が発症し 両群間に有意差を認めたとの報告があり, high risk group に対する化学療法による血小板減少療法が推奨されてい る ${ }^{12)}$. 血小板数は手術の影響で一時的に低下したが徐々に 増加し 130 万/ $\mu 1$ になった時点で化学療法としてヒドロキ シウレア（ハイドレア）の投与を追加し， 100 万/ $\mu 1$ 前後 に管理した（図 3). 抗凝固療法はへパリン投与から問題 なく経口投与へと移行でき, 術後の UCGでは明らかな心 内血栓を認めなかった。本態性血小板血症を合併した人工 
弁置換術後においても血小板数のコントロールがついてい れば通常どおりの TT 管理で問題ないものと思われる.

本態性血小板血症のおもな死因は血栓塞栓症であ る ${ }^{3,5}$. 通常, high risk group に相当する本態性血小板血 症に対する血小板数の管理は化学療法下に 60 万/ $\mu 1$ 以下 （高齢者では 80 万/ $\mu 1$ 以下）が推奨されている3,12,13) が, 本態性血小板血症を合併した人工弁置換術に関する報告は 希であり明確な血小板数の指標がないのが現状である. 無 症状ではあっても異常に血小板数が多い症例（150万/ $\mu 1$ 以上）や，若年者であっても血小板数が 80 万/ $\mu 1$ 以上で あれば治療を開始することが多いこと音, また, 現在, バ イアスピリン，ワーファリン，およびヒドロキシウレアを 内服しているが, 本態性血小板血症の相反する易出血性傾 向を考慮して，われわれは血小板数の指標を通常より高め の 100 万/ $\mu 1$ 以下として管理している. 今後の治療目標と しては厳重な血小板数のコントロール下に, 生体弁による 大動脈弁位人工弁置換術後ではあってもワーファリンを加 えた抗凝固療法を念頭においた経過観察が必要であると思 われる。

\section{結 語}

本態性血小板血症を合併した大動脈弁狭窄症に対し，生 体弁による大動脈弁位人工弁置換術を施行した。術中はへ パリンにて ACT 400 秒以上に維持し, 術後はワーファ リン，バイアスピリン，ハイドレアを投与して TTを $30 \%$ 前後, 血小板数を 100 万 $/ \mu 1$ 前後にコントロールし, 血栓症を認めなかった. また, 易出血性傾向も認めなかっ た. 今後, 血小板数のコントロールおよび抗凝固療法は厳 重な管理が必要である。

\section{文献}

1）宮崎 勢, 福田光之, 三浦 亮: 本態性血小板血症の病態に 関する検討. 臨床血液 $27: 2254-2260,1986$.

2）安永幸二：血小板異常症. 新内科学体系, 50B一血液造血器 疾患 2B. 中山書店, 東京, 1978, pp. 110-112.

3）藤村欣吾：血小板の臨床, IV. 治療方針, 2. 本態性血小板血 症治療の考元方. 日内会誌 89:1121-1125, 2000.

4) Murphy, S., Peterson, P., Iland, H. et al. : Experience of the polycythemia vera study group with essential thrombocythemia: a final report on diagnostic criteria, survival, and leukemic transition by treatment. Semin. Hematol. 34 : 29-39, 1997.

5）池田康夫：本態性血小板血症をどう治療するか. 臨床血液 $42: 447-451,2001$.

6）野並芳樹, 笹橋 臨, 佐藤幸治ほか：本態性血小板血症患者 における僧帽弁位人工弁置換術の 1 経験. 日胸外会誌 41 : 1567-1572, 1993.

7) Schött, U. : Essential thrombocythemia and coronary artery bypass surgery. J. Cardiothorac. Vasc. Anesth. 8: $552-555,1994$.

8）家村順三, 佐藤達朗, 安藤史隆 : 本態性血小板血症を合併し た左前下行枝閉塞例に対する冠動脈バイパス術の 1 治験 例. 日胸外会誌 39: 1237-1241, 1991.

9) Yoshida, H., Hoshino, T., Ishida, T. et al. : Essential thrombocythemia associated with angina pectoris with unusual coronary artery findings. Chest 100 : 1162-1163, 1991.

10）河野康治, 竹内靖夫, 五味昭彦ほか：本態性血小板血症を合 併した狭心症患者における冠状動脈バイパス術の 1 治験 例. 日胸外会誌 $45: 55-58,1997$.

11) Momiyama, T., Hiranaka, T., Nomura, F. et al. : Coronary artery bypass grafting for left main trunk coronary artery lesion associated with essential thrombocythemia. Clin. Cardiol. 16 : 691-693, 1993.

12) Cortelazzo, S., Finazzi, G., Ruggeri, M. et al.: Hydroxyurea for patients with essential thrombocythemia and a high risk of thrombosis. N. Engl. J. Med. 332 : 1132-1136, 1995.

13）松村 到, 金倉 譲：VIII. 血液疾患編. 6. 血小板増多症. 綜合 臨牀 増刊号 51：626-630, 2002. 